The Polish Journal of the Arts and Culture. New Series 8

(2/2018): 7-33 [ARTYKUะ]

DOI: $10.4467 / 24506249$ PJ.18.014.10831

\title{
Szkielet znaczeń. Meksykański kult Santa Muerte w perspektywie semiotycznej
}

\author{
Piotr Grzegorz MichaLIK
}

\begin{abstract}
Streszczenie
Artykuł stanowi przegląd wybranych aspektów kultu Santa Muerte (Świętej Śmierci) w Meksyku z perspektywy semiotycznej. Wśród meksykańskich świętych ludowch Santa Muerte wyróżnia niezwykła popularność stale rosnąca w ostatnich dekadach oraz wyjątkowa łatwość w absorbowaniu elementów najróżniejszych nurtów religijności popularnej, w tym komercyjnej ezoteryki, neopogaństwa i kubańskiej santerii. Zjawiska te można wyjaśnić wskazując na zespół szczególnych cech Świętej Śmierci pozwalający kwalifikować ją jako „soczewkę semantyczną".
\end{abstract}

Słowa kluczowe: Santa Muerte, Meksyk, święci ludowi, semiotyka

dr Piotr Grzegorz Michalik adiunkt w Katedrze Porównawczych Studiów Cywilizacji Uniwersytetu Jagiellońskiego. Od roku 2007 regularnie prowadzi badania terenowe w Meksyku, zrealizował również kilka wypraw badawczych w Gwatemali i na Kubie. Autor wyróżnionych publikacji na temat kultu świętych ludowych w Meksyku oraz rdzennych wierzeń z obszaru Mezoameryki.

E-MAIL: piotr.michalik@uj.edu.pl 


\section{Wprowadzenie}

Spośród różnorodnych fenomenów, których badaniem zajmują się antropologowie i religioznawcy, procesy synkretyczne wydają się domagać analiz z perspektywy semiotycznej niejako z własnej natury. Trudno wyobrazić sobie interpretowanie oraz tworzenie modeli teoretycznych zjawisk, takich jak nakładanie się obrazów postaci wywodzących się z odmiennych kontekstów kulturowych, obustronną translację elementów rytualnych na systemy wierzeń czy zmiany w ustalonej interpretacji symbolu bez sięgnięcia po choćby najbardziej podstawowe narzędzia badawcze z obszaru semiotyki.

W dalszej części niniejszego tekstu chciałbym przedstawić kilka refleksji, które nasunęły mi się przy okazji badań terenowych prowadzonych w latach 2015-2017 w Meksyku i na Kubie ${ }^{1}$. Dzięki nim udało się znacznie rozszerzyć i dokładniej opisać wybrane problemy pojawiające się w zarysie podczas realizacji wcześniejszych projektów badawczych ${ }^{2}$. Głównym tematem badań był kult meksykańskich świętych ludowych, niekiedy utożsamianych z synkretycznymi orishas - postaciami mitycznymi z wierzeń afrokubańskich. Niewątpliwie najbardziej złożonym i poniekąd odzwierciedlającym w mikroskali całą panoramę meksykańskiej religijności popularnej systemem wierzeń i praktyk religijnych okazał się kult Santa Muerte (Świętej Śmierci). Pomimo ogromnego zainteresowania ze strony prasy (w tym szczególnie bulwarowej) czy wyraźnej obecności w sferze popkultury (od filmu po nadruki na koszulkach i coraz bardziej popularne tatuaże), których oddziaływanie rozpościera się nie tylko Meksyk i kraje ościenne, ale również Europę, liczba rzetelnych opracowań akademickich podejmujących problem tej postaci wciąż pozostaje relatywnie niewielka.

Santa Muerte jest świętą ludową przedstawianą w postaci okolonego aureolą, zakapturzonego szkieletu wyposażonego w kosę. Celem tego krótkiego artykułu jest zarówno elementarne wprowadzenie polskojęzycznego czytelnika w problematykę meksykańskiego kultu Świętej Śmierci, jak i ogólne

${ }^{1}$ Artykuł powstał w wyniku realizacji projektu badawczego nr 2014/13/D/HS1/o1695 finansowanego ze środków Narodowego Centrum Nauki.

${ }^{2}$ Niektóre spośród wspomnianych w niniejszym tekście koncepcji, sformułowanych w zalążkowej postaci wyniku badań terenowych prowadzonych w ramach projektów badawczych w latach 2007-2008 i 2011 dzięki stypendiom meksykańskiej Secretaría de Relaciones Exteriores, zostały przedstawione $\mathrm{w}$ prezentacji mającej miejsce podczas 1oth World Congress of Semiotics w La Coruña w 2009 roku. Zostały one w znacznej mierze zweryfikowane i rozszerzone w wyniku realizacji wyżej wymienionego projektu badawczego. 
podsumowanie najważniejszych wniosków wynikających ze wspomnianych wyżej badań terenowych poprzez wskazanie kilku wymiarów, w których wykorzystanie podstawowych koncepcji semiotycznych (takich jak, między innymi, nakładanie się obrazów, kontaminacja czy semioza) wzbogaca lub rozjaśnia wyniki badań nad omawianą problematyką prowadzonych z perspektywy antropologicznej i religioznawczej.

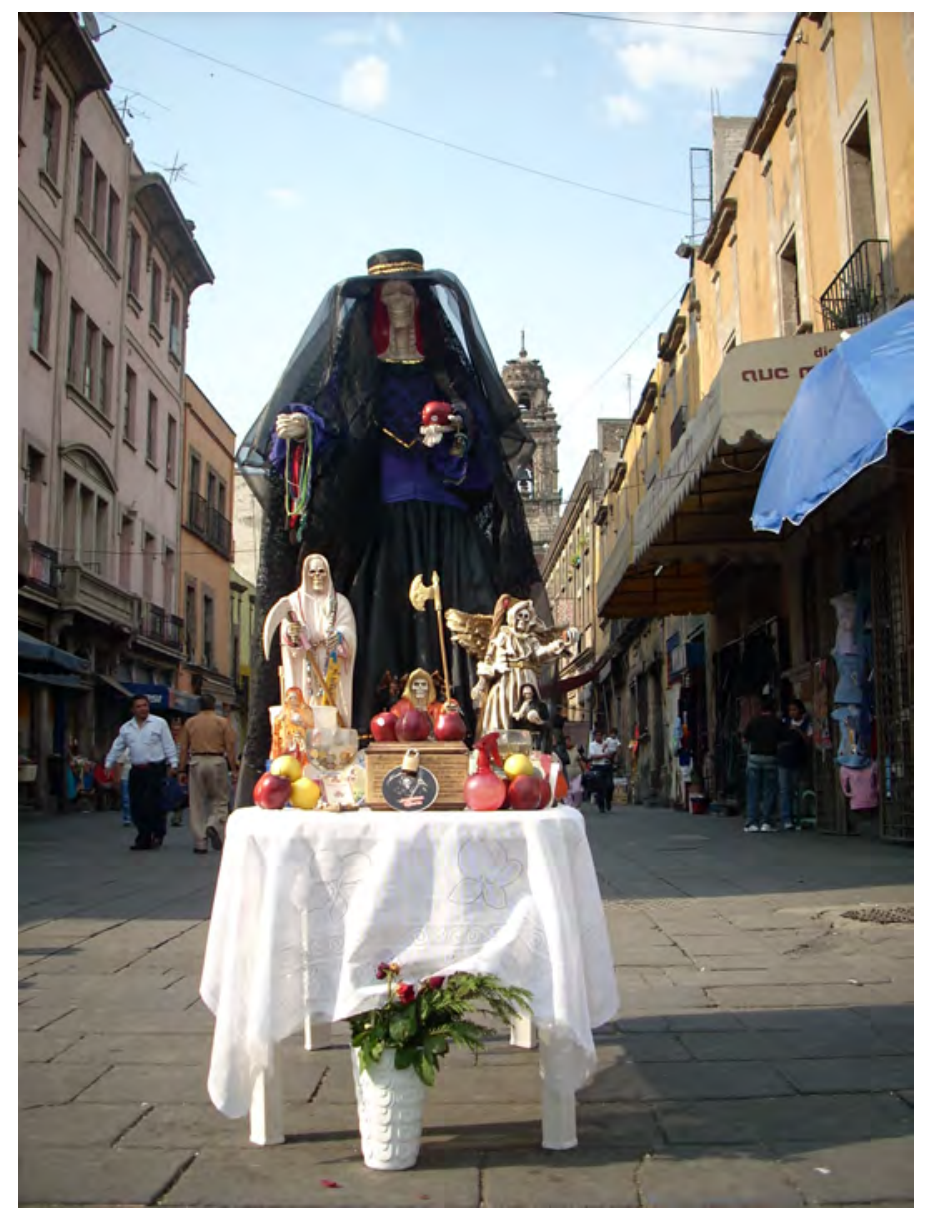

Fot. 1: Przenośny ołtarz Świętej Śmierci w centrum Mexico City.

Szczególnie gwałtowny wzrost popularności zarówno kultu, jak i samego przedstawienia ikonograficznego Santa Muerte (nie tylko w Meksyku, ale również w sąsiednich krajach, w Gwatemali, Salwadorze i USA) nastąpił w ciągu ostatnich dwóch dekad. Pomimo obszernej literatury dotyczącej 
Santa Muerte w postaci artykułów prasowych oraz broszur i czasopism przeznaczonych dla wyznawców, a także wszelkiego rodzaju witryn internetowych, przez wiele lat kult pozostawał na uboczu zainteresowań badawczych antropologów, historyków czy socjologów³ .

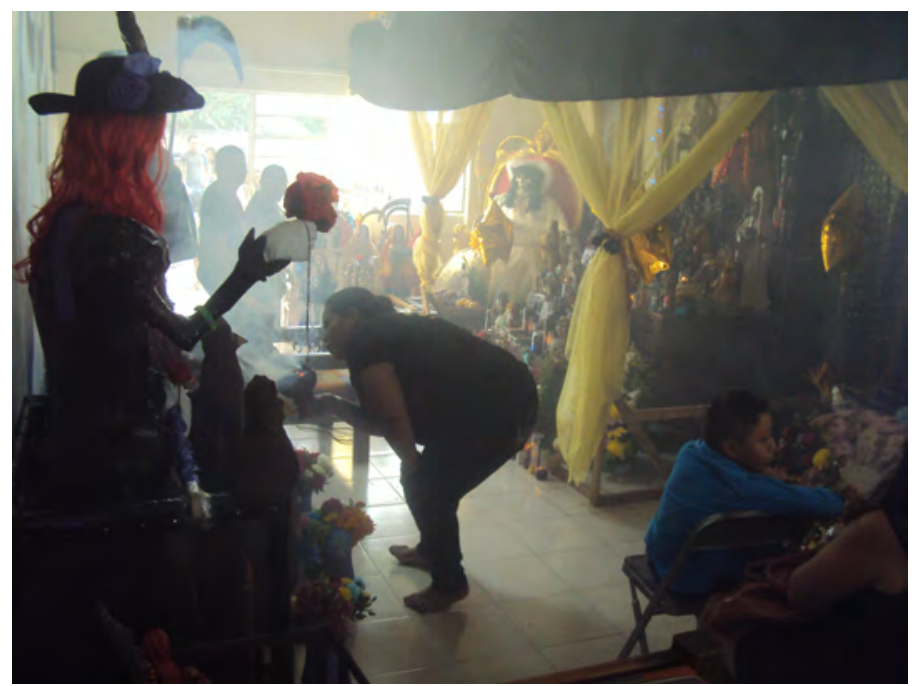

Fot. 2: Doña Karla dokonuje rytualnego okadzenia figur podczas modlitwy różańcowej skierowanej do Santa Muerte, kapliczka Świętej Śmierci doñi Karli, Mérida, Jukatan, Meksyk.

Santa Muerte, w przeciwieństwie postaci takich jak choćby Dziewica z Juquila, jest jedną z nieformalnych meksykańskich świętych ludowych. Oddawanie jej czci, podobnie jak innym nieformalnym świętym (wśród nich między innymi Jesusowi Malverde, San Juananowi Soldado, Maximonowi itd.), nie tylko nie cieszy się poparciem Kościoła Katolickiego, ale pozostaje przezeń surowo potępiane.

Tym niemniej, w swej najbardziej popularnej wersji kult Świętej Śmierci pozostaje jedną z form meksykańskiego katolicyzmu ludowego. Elementy liturgii charakterystyczne dla Kościoła Katolickiego, takie jak czynienie znaku krzyża, odmawianie modlitw różańcowych i nowenn czy meksykańskich

3 Wzmożone zainteresowanie badaczy tematem Świętej Śmierci trwa zaledwie od około dekady. Wśród pionierskich publikacji można wymienić między innymi K. Perdigón Castañeda, La Santa Muerte. Protectora de los hombres; A. R. Chesnut, Devoted to Death. Santa Muerte, the Skeleton Saint; E. Malvido, Crónicas de la Buena Muerte a la Santa Muerte en México; C. Adeath, C., R. Kristensen, La Muerte de tu lado; J. A. Flores Martos, La Santísima Muerte en Veracruz, México: vidas descarnadas y prácticas encarnadas. 
mañanitas dominują we wzorcach zachowań rytualnych wyznawców Santa Muerte. Adoracja obrazu Świętej Śmierci, jak również akt składania na ołtarzu ofiar z jabłek, słodyczy i tytoniu stanowią podstawowe elementy praktyki kultowej. Wielu miejskich uzdrawiaczy uznaje Santa Muerte za swoją świętą patronkę.

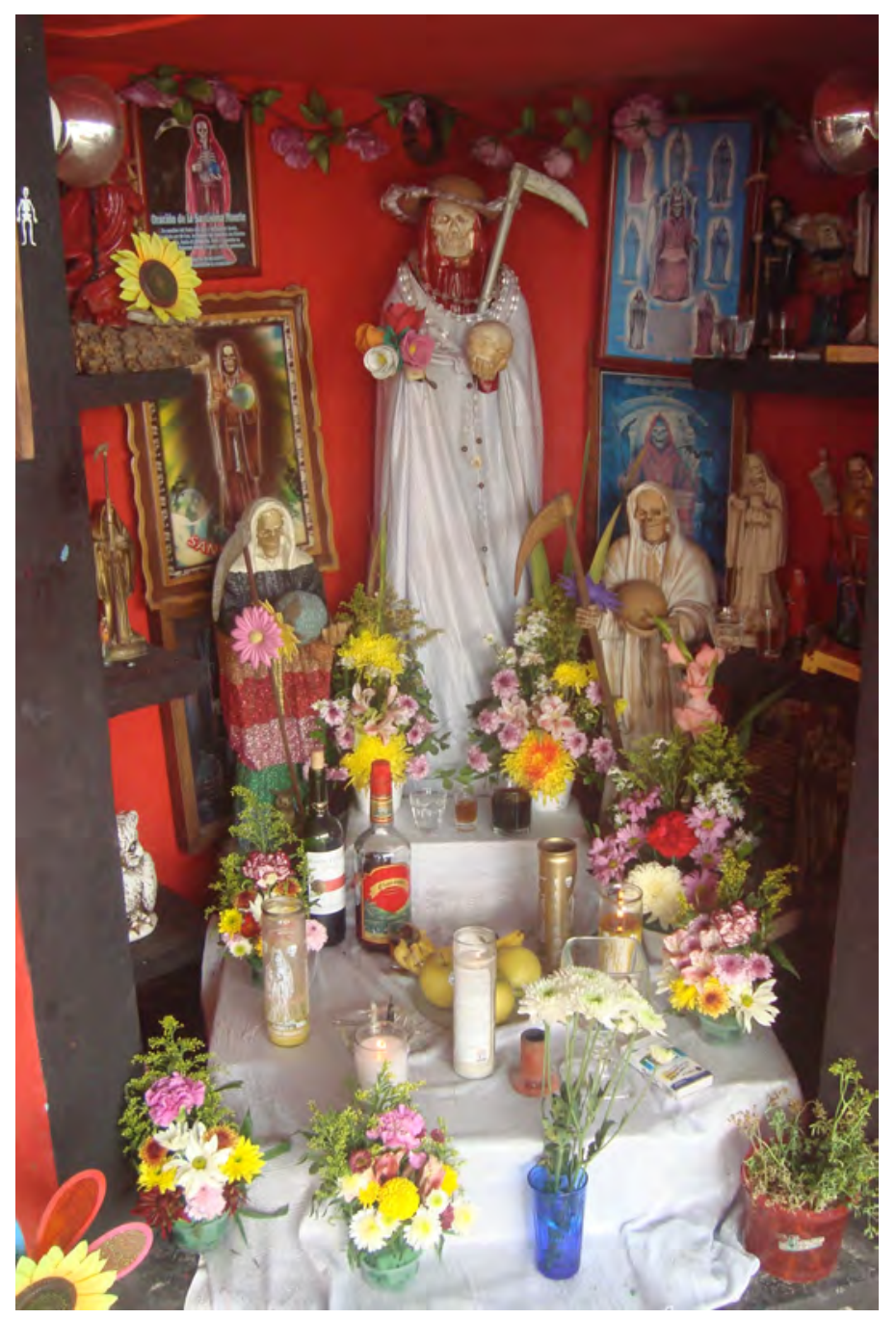

Fot. 3: Kapliczka Świętej Śmierci doñi Teresy, Mérida, Jukatan, Meksyk.

Według meksykańskich historyków podejmujących problem genezy ikonografii Santa Muerte, w Meksyku i Gwatemali przykłady adoracji obrazów przedstawiających szkielet wyposażony w kosę można odnaleźć już w XVII 
i XVIII wieku. Adorowane szkieletowate postacie to przede wszystkim Justo Juéz i Presagiadora, patroni religijnych stowarzyszeń (cofradias) pod wezwaniem Dobrej Śmierci (Buena Muerte) ${ }^{4}$. Jeszcze bardziej wyrazisty jest wpływ Gwatemalskiego kultu świętego ludowego San Pascuala pochodzący z XVII wieku ${ }^{5}$. Jednakże najstarsze udokumentowane przypadki istnienia wierzeń związanych z Santa Muerte występującą we właściwej sobie, szkieletowatej postaci, posiadającą gramatycznie płeć żeńską oraz zawierających zestaw rytuałów, symboli i elementów ikonograficznych charakterystycznych dla współczesnego kultu sięgają zaledwie pierwszej połowy XX wieku' ${ }^{6}$.

Przez kilka dekad kult był sprawowany przede wszystkim indywidualnie lub w niedużych grupach i pozostawał na marginesie zainteresowania szerszego grona odbiorców. Dopiero w latach 90. XX wieku nastąpił gwałtowny wzrost rozwoju zainteresowania kultem w większych ośrodkach miejskich, ze stolicą Meksyku na czele. w tym samym czasie Santa Muerte pojawiła się po raz pierwszy w publicznej debacie. Ołtarz Świętej Śmierci znaleziony podczas policyjnej interwencji w domu słynnego porywacza, przywódcy zorganizowanej grupy przestępczej Daniela Arizmendi Lópeza uczynił kościstą świętą atrakcją prasy bulwarowej.

Dyskurs prasowy z tamtego okresu ogłosił Santa Muerte patronką kryminalnego półświatka. Dziennikarze z czasopism takich jak La Crónica czy La Prensa prześcigali się w sensacyjnych doniesieniach dotyczących domniemanego satanicznego i perwersyjnego kultu śmierci, nie stroniącego od ofiar z ludzi.

Przełomowym wydarzeniem w najnowszych dziejach kultu było ustanowienie w 2001 roku pierwszego ulicznego, otwartego publicznie ołtarza Świętej Śmierci przez Enriquetę Romero Romero. Ołtarz powstał w kolonii Morelos w Mexico City. Każdego miesiąca organizowano przy nim modlitwy różańcowe poświęcone Santa Muerte, na które przybywali pielgrzymi z różnych części stolicy, a z czasem z całego Meksyku i innych krajów. Od 2001 roku w pozostałych dzielnicach miasta i na terenie całego kraju wciąż

4 E. Malvido, op. cit.

5 Jednym z najważniejszych opracowań poświęconych temu świętemu ludowemu jest C. Navarrette, San Pascualito Rey y el culto a la muerte en Chiapas.

6 Zob. O. Lewis, Los hijos de Sanchez, s. 306. Istnieją znacznie starsze, bo pochodzące z dokumentu z końca XVIII wieku wzmianki dotyczące kultu szkieletowatej postaci nazywanej Santa Muerte, jednak nie dostarczają one dostatecznie obszernych danych, aby móc stwierdzić, że wspomniane w nich praktyki rytualne pozostają dostatecznie zbliżone do tych zarejestrowanych w XX wieku. Zob. K. Perdigón Castañeda, op.cit. s. 33. 
powstają kolejne ołtarze i kapliczki. Ich stale rosnącej liczby nie udało się dotychczas oszacować nawet w przybliżeniu.

Wraz z powstaniem ołtarza doñi Enriquety Romero Romero przełom dokonał się również w sposobie przedstawiania Świętej Śmierci przez prasę. W czasopismach takich jak La fornada oraz El País starano się zaprezentować kult w sposób bezstronny. Dostrzeżono, że zdobywa on popularność przede wszystkim pośród przedstawicieli najmniej uprzywilejowanych warstw społecznych: niezamożnych gospodyń domowych, drobnych przedsiębiorców, robotników itd.

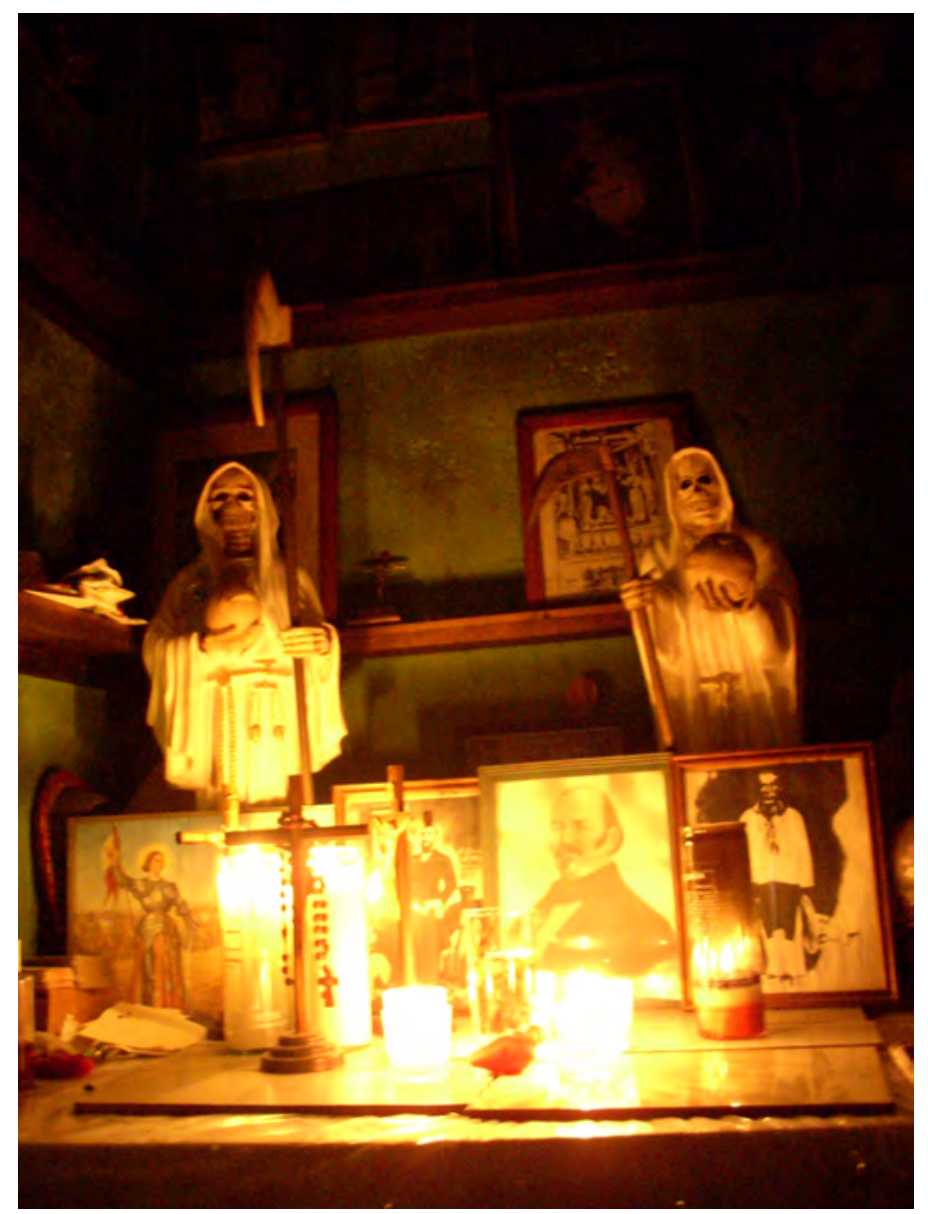

Fot. 4: Ołtarz Świętej Śmierci miejskiego uzdrawiacza-spirytualisty, San Cristóbal de las Casas, Chiapas, Meksyk. 


\section{Dziewica bez twarzy}

Rytuał, ikonografia i system wierzeń powiązane z postacią Santa Muerte zapożyczone zostały z różnych źródeł. Najbardziej rozpoznawalny pozostaje bezsprzecznie chrześcijański język reprezentacji i symboli. Jak słusznie zauważa Flores Martos, wbrew rozpowszechnionej opinii postać Santa Muerte wykazuje znacznie więcej wspólnych elementów z Dziewicą z Guadalupe niż na przykład z Mictlantecuhtlim i Mictlantecihuatl, prekolumbijskimi bóstwami śmierci ${ }^{7}$ Na płaszczyźnie wizualnej podobieństwa łączące Świętą Śmierć z Dziewicą z Guadalupe stają się wyraźne już przy okazji analizy jednego z najstarszych wariantów ikonograficznych przedstawiających tę pierwszą, znanego ze stanowiących przedmiot kultu obrazków pochodzących z pierwszej połowy XX wieku. Widnieje na nich Santa Muerte otoczona aureolą i okryta tuniką. Innym znakomitym przykładem nakładania się ikonografii tych dwóch postaci jest przedstawienie Santa Muerte w formie znanej jako piadosa, odtwarzającej klasyczną kompozycję Pietà, w której Święta Śmierć obejmuje ludzkie zwłoki, przyjmując pozę Maryi Dziewicy trzymającej w ramionach Chrystusa. Na poziomie leksykalnym izomorfizm między tymi dwiema postaciami uwyraźnia się choćby w często używanym zwrocie „okryj nas swoim świętym płaszczem” (cúbrenos con tu Santo Manto), wykorzystywanym podczas modlitw różańcowych odbywających się przy ołtarzu doñi Enriquety. Zwrot ów jest charakterystyczny dla modlitw skierowanych do Maryi Dziewicy. Podobnie, jedno z najczęstszych określeń kościstej świętej „nasza Matka”, używane jest również w odniesieniu do Maryi Dziewicy (w kontekście meksykańskim przede wszystkim Dziewicy z Guadalupe). Obie postacie łączone są ponadto z symboliką lunarną. Mimo że nie stanowi to powszechnego elementu wyobrażeń wyznawców, można niekiedy spotkać się z przykładami przekodowywania tych wizualnych i leksykalnych identyfikacji na system wierzeń. w niektórych przypadkach Santa Muerte bywa bowiem bezpośrednio utożsamiana z Dziewicą z Guadalupe ${ }^{8}$.

Wymienione powyżej przykłady wielopoziomowego synkretycznego nakładania się obrazów postaci lub ich aspektów wykazują zauważalne podobieństwo do wzorców kontaminacji, opisanych przez Borysa Uspienskiego w jego kompleksowym studium procesów synkretycznych związanych z kultem świętego Mikołaja na Rusi ${ }^{9}$.

7 J. A. Flores Martos, op. cit., s. 281-282.

8 Zob. P. G. Michalik, Death with a Bonus Pack: New Age Spirituality, Folk Catholicism and the Cult of Santa Muerte, s. 171-173.

9 B. Uspieński, Kult Świętego Mikołaja na Rusi. 


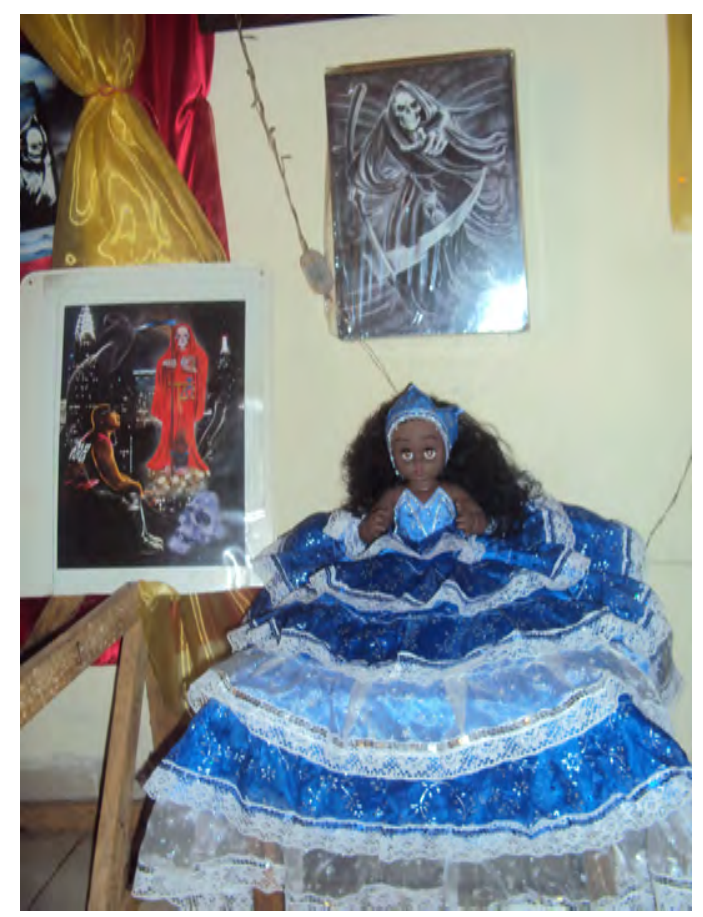

Fot. 5: Orisha Yemayá z kubańskiej santerii w pobliżu ołtarza Santa Muerte, kapliczka Świętej Śmierci doñi Karli, Mérida, Jukatan, Meksyk.

Santa Muerte nierzadko bywa bezpośrednio łączona również z innymi nieformalnymi świętymi należącymi do świata meksykańskiego katolicyzmu ludowego. Bywa utożsamiana z postacią wspomnianego San Pascuala, żoną Jesusa Malverde lub pomocniczką Niño Fidencio. w polu wzajemnego oddziaływania z kultem Świętej Śmierci znajduje się również meksykańska tradycja spirytualistyczna, blisko powiązana z ludowymi praktykami leczniczymi, uzdrawiającymi oraz popularną ezoteryką w kontekście miejskim ${ }^{10}$. Najpopularniejszy nurt spirytualistyczny w Meksyku - Espiritualismo Trinitario Mariano - stworzył eklektyczną hierarchię istot duchowych, wśród których Biała Siostra (Hermana Blanca) - utożsamiana z Santa Muerte - zajmuje wysoką pozycję ${ }^{11}$. w rejonie portu Veracruz Święta Śmierć, jako „Biały Kwiat Wszechświata” (Flor Blanca del Universo) łączona jest z postacią Yemayá ${ }^{12}$.

${ }^{10}$ Zob. P. G. Michalik, op. cit., s. 170-171.

${ }^{11}$ Zob. monografie na temat meksykańskiego spirytualizmu s. Ortiz Echaniz, Una religiosidad popular: el espiritualismo trinitario mariano i I. Lagarriga Attias, Espiritualismo trinitario mariano. Nuevas perspectivas de analisis.

${ }^{12}$ J. A. Flores Martos, op. cit., s. 292-302. 
Jest to jedna z istot mitycznych (orishas) wywodzących się z afrokubańskiego systemu wierzeń i rytuałów nazywanego santería. Santa Muerte ucieleśniona jako „Biały Kwiat Wszechświata” przedstawiana jest w postaci kształtnej, pięknej kobiety. Podkreślane się tu jej matczyne i kobiece aspekty.

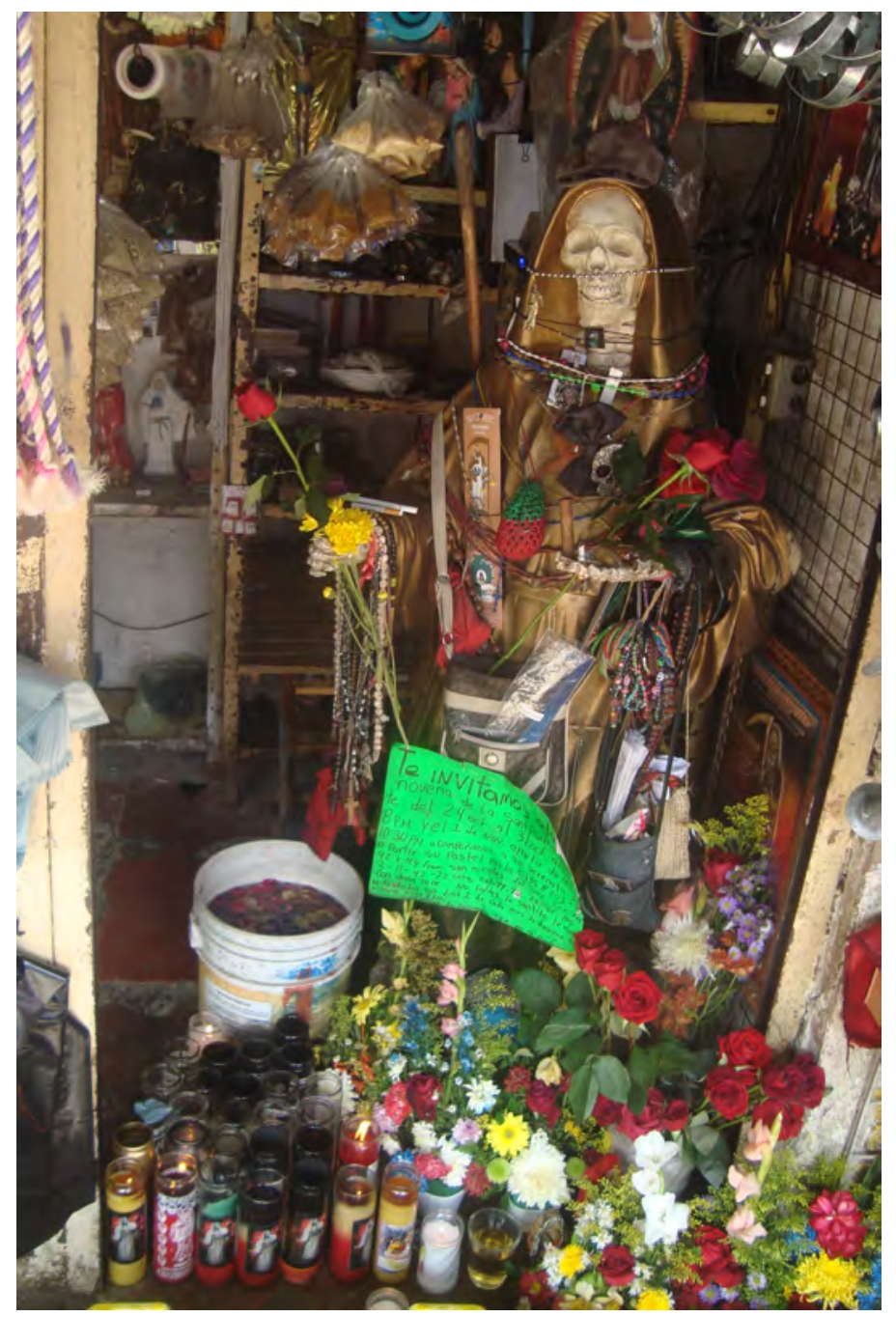

Fot. 6: Figura i ołtarzyk Świętej Śmierci przy stoisku ezoterycznym, rynek Lucas de Gálvez, Mérida, Jukatan, Meksyk. 


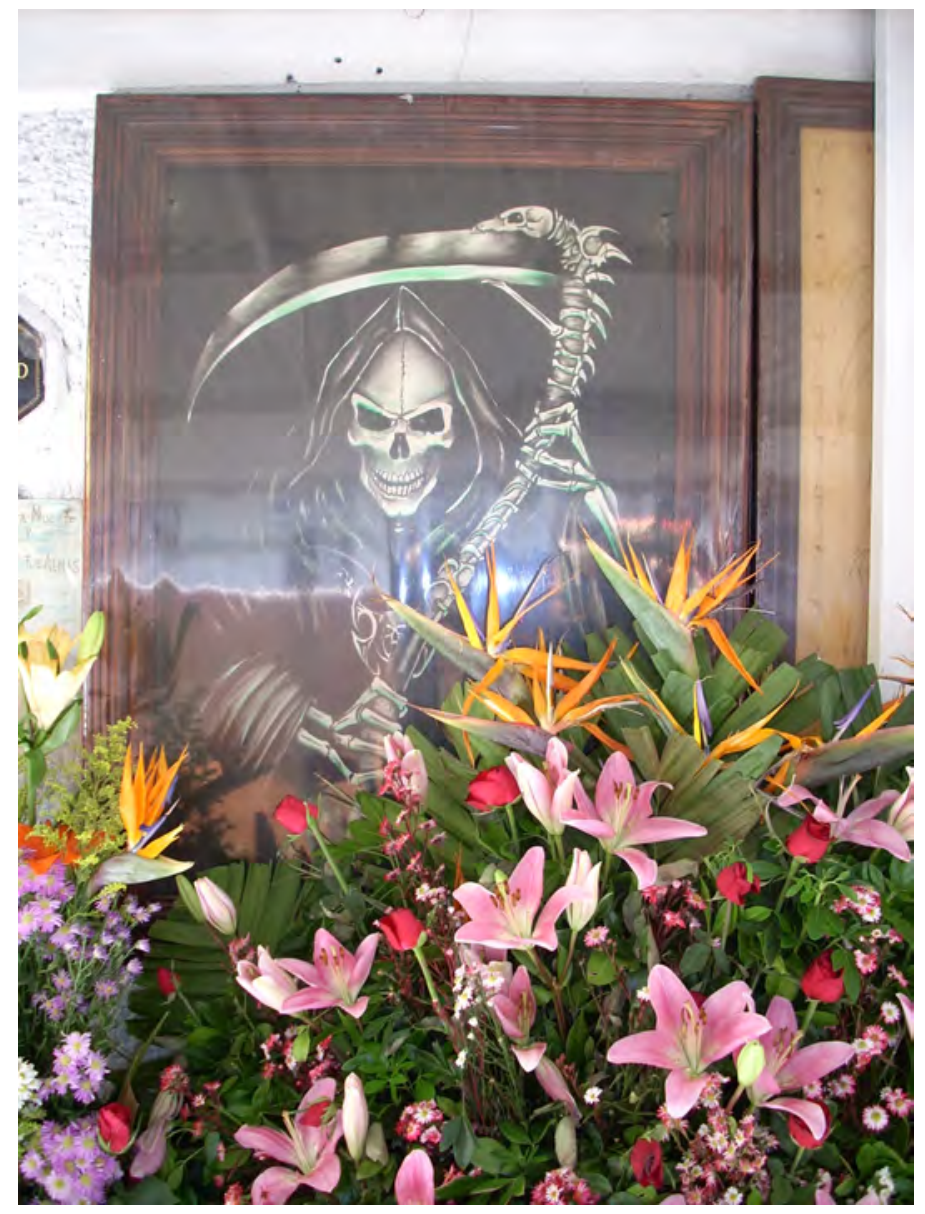

Fot. 7: Wizerunek Świętej Śmierci w konwencji Heavy Metal/fantasy, ołtarz doñi Enriquety, Mexico City.

\section{3 Święta Żarłoczna}

Zdumiewająca łatwość, z jaką kult Santa Muerte absorbuje niezliczone elementy heterogenicznych kodów wizualnych, gramatyki rytualnej i systemów wierzeń ma kilka podstawowych uzasadnień.

Po pierwsze, w najogólniejszym ujęciu, od czasów kolonialnych religijną panoramę Meksyku kształtowały interakcje zachodzące pomiędzy odrębnymi systemami wierzeń i praktykami religijnymi różnego pochodzenia, wśród nich przede wszystkim rdzennymi, chrześcijańskimi i afrokaraibskimi ${ }^{13}$.

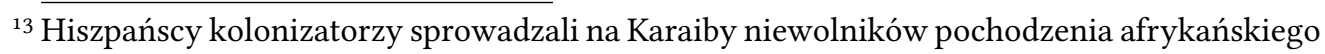


Po drugie, wierzenia i praktyki rytualne składające się na kult nieformalnych świętych (w tym praktyki miejskich uzdrawiaczy) nie są skonsolidowane w formie jednolitego zestawu dogmatów czy liturgii przez żadną konkretną instytucję. Pomimo kilkakrotnie podejmowanych prób zjednoczenia wyznawców Świętej Śmierci, nie istnieje jedna powszechnie uznawana organizacja, która skupiałaby większość wyznawców i ograniczałaby różnorodność praktyk w obrębie kultu. Stąd skrajne rozbieżności dotyczące szczegółów rytuału, interpretacji poszczególnych symboli, a nawet sposobu rozumienia charakteru i funkcjonowania samej postaci Świętej Śmierci pojawiają się nawet w obrębie niewielkich społeczności wyznawców.

Innym czynnikiem, który nie pozostaje bez wpływu na „semiotyczną żarłoczność" ${ }^{14}$ kultu Świętej Śmierci jest jej rosnąca popularność w nowoczesnym (lub, jeśli ktoś woli, ponowoczesnym) społeczeństwie konsumpcyjnym, tonącym w powodzi informacji multimedialnych. Jego uczestnicy zyskują możliwość łatwego (choć powierzchownego) dostępu do informacji dotyczących najbardziej różnorodnych i egzotycznych tradycji religijnych oraz wizualnych konwencji, w interesującym nas przypadku powiązanych z wizerunkiem szkieletu. Jednocześnie pozostają pod wpływem charakterystycznej dla współczesnej, zglobalizowanej kultury tendencji do przekształcenia każdego aspektu ludzkiego życia w towar, który mógłby zostać wybrany i ewentualnie połączony w niestandardowy sposób z innymi produktami, podobnie jak towar w centrum handlowym. Zjawisko to powiązane jest ze stopniowym kształtowaniem elementów tożsamości (w tym przypadku religijnej) na sposób konsumpcyjny, tzw. shopping mall self członków społeczeństwa konsumpcyjnego ${ }^{15}$. W interesującym nas przypadku tendencja ta przejawia się przez niebywałą komercjalizację kultu Santa Muerte oraz zalew produktów zaprojektowanych i wykonanych specjalnie dla jego wyznawców.

już od 1501 roku. Ich liczba w Nowej Hiszpanii stale rosła w XVI i XVII wieku a wraz z nią, niejawnie, oddziaływanie wierzeń i praktyk religijnych z obszaru Afryki. Na temat wpływów afrykańskich na praktyki magiczne w kolonialnym Meksyku zob. G. Aguirre Beltrán, Medicina y magia. El proceso de aculturación en la estructura colonial. Współcześnie oddziaływania afrokaraibskich wierzeń i praktyk rytualnych, takich jak kubańska santeria, nasilają się w Meksyku od lat 2o. XX wieku, wraz narodzinami ma Kubie tzw. „movimiento afrocubano" propagującego w kręgach artystycznych, literackich i muzycznych sztukę nasiąkniętą wpływami afrykańskimi. Na temat Santerii oraz jej wpływu na współczesną meksykańską religijność popularną zob. drobiazgową monografię N. B. Juárez Huet, Un pedacito de dios en casa. Circulación transnacional, relocalización y praxis de la santería en la Ciudad de México.

${ }^{14}$ Zob. J. A. Flores Martos, op. cit., s. 292.

${ }^{15}$ L. Aldred, Plastic Shamans and Astroturf Sundances. New Age Commercialization and Native American Spirituality, s. 329-352. 
O komercyjnym aspekcie kultu możemy wiele dowiedzieć się z krzykliwych magazynów skierowanych do wyznawców Świętej Śmierci, które wyróżniają się własną, charakterystyczną stylistyką. Najpopularniejszym czasopismem skierowanym do wyznawców Świętej Śmierci jest Devoción a la Santa Muerte, wydawane przez Mina Editores. Zawartość czasopisma obejmuje zdjęcia ołtarzy, listy od czytelników, wskazówki rytualne, objaśnienia symbolicznego znaczenia poszczególnych elementów ikonografii oraz oczywiście reklamy. Te ostatnie pozwalają badaczowi ustalić docelowego odbiorcę magazynu, a także określić religijny kontekst komercyjnego wymiaru, w którym umieszczono Świętą Śmierć. Natkniemy się zatem na ogłoszenia, w których miejscy uzdrawiacze oferują usługi, takie jak rytualne oczyszczanie energetyczne (limpias energéticas), czytanie z kart Tarota, praktyki magiczne, ochronę przed negatywnymi oddziaływaniami oraz pomoc w sprawach miłości, zdrowia, pieniędzy i innych problemach osobistych. Pomiędzy nimi umieszczone są reklamy gorących linii horoskopowych i wróżbiarskich czatów oferujących przewidywanie przyszłości z pomocą Tarota, run i numerologii. Reklamowe są również akcesoria i podręczniki do Feng Shui. Produkty powiązane z Santa Muerte, na przykład instruktażowe płyty DVD z rytuałami, często sprzedawane są $\mathrm{w}$ zestawie $\mathrm{z}$ bonusami, takimi jak świece i broszury poświęcone tematyce magicznej. Logika handlu wymaga wprowadzania ciagłych zmian w opakowaniach tego samego produktu, wszelkie nowe, egzotyczne etykiety są również mile widziane. w tym aspekcie kultu Santa Muerte, swobodnie przyjmowane elementy heterogenicznych rytualnych i mitycznych języków zostają semantycznie zredukowane, przekodowane i ujednolicone tak, aby mogły stać się rozpoznawalnym, gotowym i przyjaznym dla użytkownika produktem, który może być łatwo zestawiany z innymi dostępnymi towarami. Wyrazistym przykładem może być tu ezoteryczna hybryda ikonografii Santa Muerte i kart Tarota. Kolejnym przejawem tego samego procesu jest ogromny i stale zwiększający się asortyment masowo produkowanych akcesoriów wykorzystujących wizerunek Świętej Śmierci: statuetki, wisiorki, naszyjniki, t-shirty, a nawet tapety do telefonów komórkowych. To gwałtowne namnożenie form i rytualnomityczna wielojęzyczność napędzane logiką handlu mają oczywiście wpływ na język przedstawień, gramatyki rytualnej i mitologii kultu Santa Muerte.

W pierwszej połowie XX wieku praktyki rytualne kultu znajdowały się przede wszystkim pod wpływem meksykańskiego katolicyzmu ludowego. Odbywały się przy skromnym ołtarzu i w wielu przypadkach ograniczone 
były jedynie do składania skromnych ofiar i odmawiania krótkich modlitw. Niewielki, papierowy znaczek z podobizną Santa Muerte często bywał jedynym jej przedstawieniem ikonograficznym zdobiącym ołtarz. Obecnie rytuał jest znacznie bardziej rozbudowany, opiera się na wielu powszechnie dostępnych akcesoriach: statuetkach, świecach, balsamach lub proszkach dostosowanych do specyfiki i celu danej ceremonii. Zmieniła się również struktura samego ołtarza. Najczęściej na ołtarzach tworzonych przez miejskich uzdrawiaczy i licznych wyznawców znajduje się wiele różnych przedstawień Świętej Śmierci. Sam wizerunek Santa Muerte również się zmienia. Choć jeszcze do niedawna aspektom tym nie przypisywano większego znaczenia, obecnie w sferze wizualnej często kładzie się nacisk na podkreślanie rzekomych prekolumbijskich korzeni kultu albo jego domniemanej religijnej uniwersalności.

\section{Słodycz czaszki}

Poszczególne sposoby reagowania na widok obrazów reprezentujących ludzkie szczątki pozostają rzecz jasna w znacznej mierze zakodowane kulturowo i ściśle zależne od kontekstu. w kontekście współczesnej kultury meksykańskiej pojawiają się pewne charakterystyczne dla niej konotacje, które mogą nieco łagodzić potencjalnie negatywny ładunek emocjonalny wywoływany niekiedy przez kontakt z omawianym obrazem w innych kontekstach. Słynna fiesta $z$ okazji Dnia Zmarłych tradycyjnie obfituje w wizerunki ludzkich szczątków. Obok, między innymi, szkieletowatych wycinanek produkty takie, jak cukrowe i czekoladowe czaszki wypełniają niezliczone witryny sklepów cukierniczych i straganów. Zwyczaj konstruowania ołtarzy z tradycyjnymi ofiarami dla zmarłych często przeradza się w imprezę integracyjną dla kolegów z pracy czy dzieci w wieku szkolnym. Jednym z najbardziej rozpowszechnionych obrazów śmierci w meksykańskiej kulturze popularnej jest Catrina, szkielet damy w wiktoriańskiej sukni, nierzadko wyraźnie dominujący w imaginarium związanym z Dniem Zmarłych. Motyw Catriny pojawia się z impetem w sztuce meksykańskiej od przełomu XIX i XX wieku, wykorzystywany ze szczególnym powodzeniem przez wielu głośnych artystów, takich jak José Guadalupe Posada czy Diego Rivera. Wizerunek ten, popularny początkowo wśród elit artystyczno-intelektualnych, szybko stał się szeroko rozpowszechnionym obrazem, występującym w formach najróżniejszych figurek pamiątkowych, ilustracji, nadruków itp. Innym przykładem jest przed- 
stawienie szkieletu z kosą nazywane La Muerte, jedna z postaci znaczącej karty w loteria mexicana, niezwykle popularnej w Meksyku grze dla dzieci. Biorąc pod uwagę, że szczątki ludzkie stanowią jeden ze szczególnie charakterystycznych motywów ikonografii prekolumbijskiej, która kształtuje istotną część współczesnego meksykańskiego dziedzictwa kulturowego, można śmiało stwierdzić, że obraz szkieletu stanowi kluczowy element wizualnego leksykonu kultury meksykańskiej jako takiej.

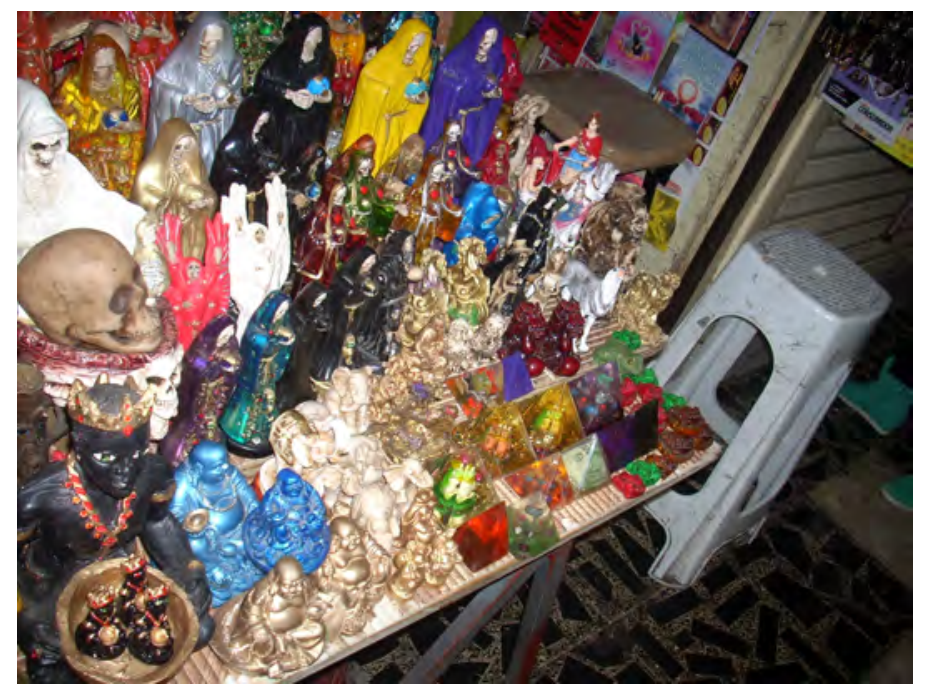

Fot. 8: Figurki orisha Changó z kubańskiej santerii, Świętej Śmierci i Buddy, stoisko ezoteryczne, rynek Sonora, Mexico City.

Tym niemniej sposób postrzegania postaci Santa Muerte przez jej oddanych wyznawców zasadniczo różni się od powszechnej interpretacji tego wizerunku. w prywatnych wizjach świata wyznawców pełni ona często rolę anioła lub szczególnie potężnej świętej. Wielu wyznawców opisuje ją jako postać matczyną, życzliwą, piękną, słodką, czasem wręcz radosną. Postawa wiernego wobec Świętej Śmierci i figurki, która ją reprezentuje, jest z reguły pełna czułości. Wyznawcy koncentrują się na jej cechach świętej ludowej, takich jak domniemana moc spełniania życzeń, czynienia cudów czy ochrona wiernych. Pytania egzystencjalno-metafizyczne dotyczące pełnionej przez nią funkcji śmierci często pozostają na uboczu. Jeśli są one w ogóle zadawane, Santa Muerte postrzegana jest zasadniczo jako posłaniec Boga, szczególna istota, której misją jest przeprowadzanie wiernych na drugą stronę. Według licznych wyznawców decyzja o zakończeniu czyjegoś życia podejmowana 
jest przez samego Boga, dlatego to on pozostaje jedynym odpowiedzialnym za istnienie i przytrafianie się śmierci.

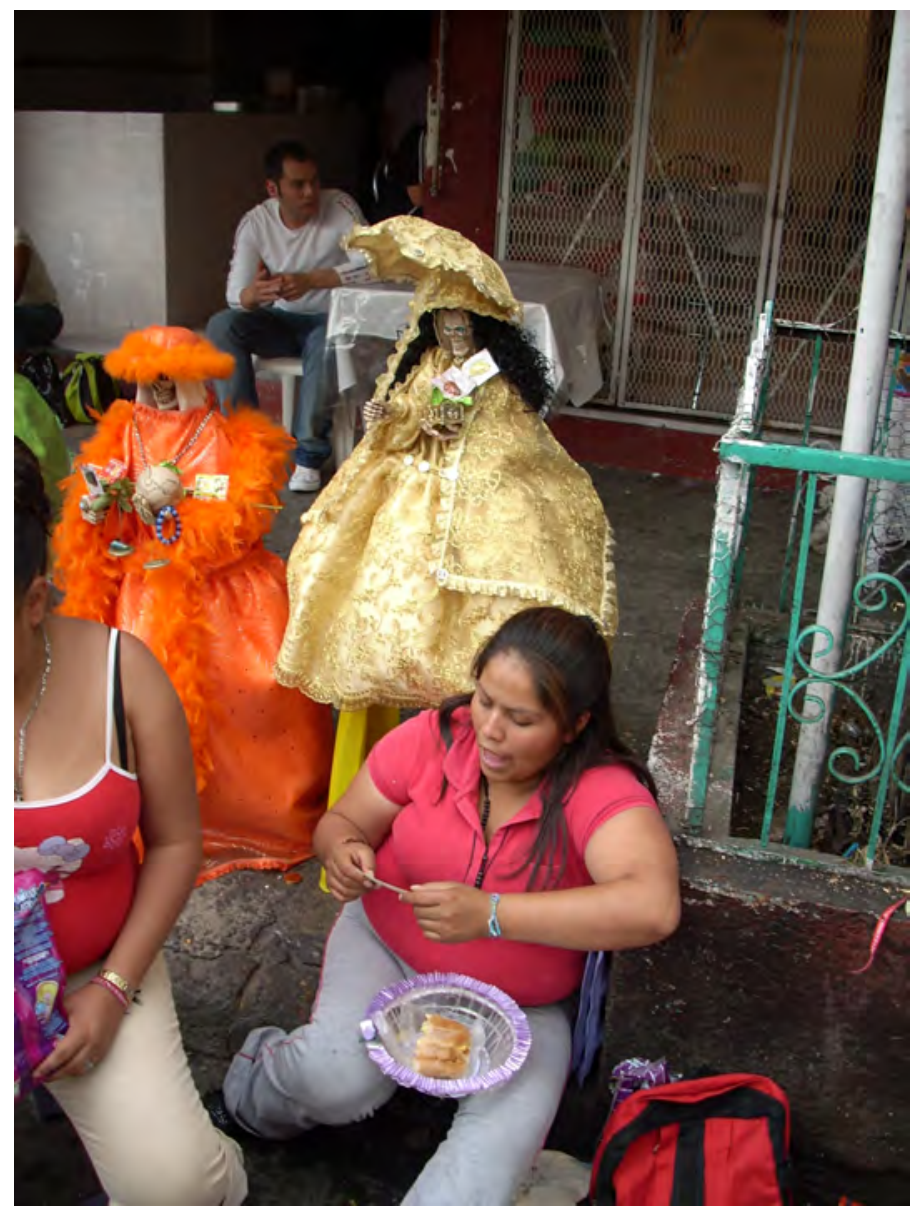

Fot. 9: Święta Śmierć jako Catrina podczas modlitwy różańcowej skierowanej do Santa Muerte, kapliczka Świętej Śmierci doñi Enriquety, Mexico City.

Wyznawcy Santa Muerte przyzwyczajają się do początkowo odstręczającego wizerunku swojej świętej patronki. Wielu z nich przestaje postrzegać jej przedstawienie ikonograficzne jako stopniowo odpychające. Szkielet z kosą staje się opiekuńczą, matczyną świętą, kojarzoną z rodzinnymi świętami i festiwalami oraz mnóstwem pozytywnych doświadczeń życiowych. Odsłanianie ukrytych dla laika, sprzecznych z powszechną intuicją znaczeń, odwrócone kodowanie, staje się dla wyznawców konwencją. 
Na płaszczyźnie leksykalnej ów proces oswajania często wyrażany jest przez nadawanie pseudonimów. Wyznawcy Santa Muerte, zwracając się do swojej patronki, używają wielu zdrobnień, takich jak Chudziutka (Flaquita), Malutka Święta (Santita) czy Śliczniutka Dziewczynka (Nina Bonita).

\section{Konkluzja: szkielet znaczeń, czyli soczewka se- mantyczna}

Ludzkie szczątki w kulturach mezoamerykańskich miały swoiste znaczenie symboliczne, wpisane w systemy wyobrażeń o świecie i wartości bardzo odmienne od europejskich. Ale nawet w kręgu kultury europejskiej obraz szkieletu bądź jego fragmentów przywołuje wyraźnie niejednorodne odwołania do konkretnych znaczeń, konotacji i preferowanych interpretacji, w zależności od kontekstu. Wystarczy przyjrzeć się choćby tak rozbieżnym przykładom, jak średniowieczny i barokowy motyw danse macabre, nazistowskie insygnia Totenkopf czy wybrane okładki płyt zespołów Heavy Metalowych. Wizerunek ludzkiego szkieletu, choć w różnych kontekstach historycznych, społecznych i kulturowych naszpikowany innymi znaczeniami, charakteryzuje się pośród wielości swoich reprezentacji znaczącymi podobieństwami, ponieważ wzorowany jest na uniwersalnej konstrukcji anatomicznej. Ów uderzający i łatwo rozpoznawalny, a zarazem polisemantyczny, obraz stymuluje do tworzenia powiązań pomiędzy odmiennymi systemami znaczeń.

W związku z podstawową ikonografią postaci Santa Muerte można postrzegać ją jako "soczewkę semantyczną". Soczewką semantyczną będę nazywał jednostkę znaczącą (może to być postać, symbol, atrybut itd.) posiadającą jednocześnie dwie istotne właściwości. Pierwszą jej właściwością jest ogniskowanie. Na podobieństwo intensywnego zapachu soczewka semantyczna przyciągnie uwagę niemal każdej osoby znajdującej się w jej pobliżu, nie pozwali przejść obok siebie obojętnie. i podobnie, jak intensywny zapach, natychmiast pobudza skojarzenia, skłania do interpretacji. To druga właściwość soczewki semantycznej: prowokowanie semiozy, zmuszanie obserwatora do przypisywania znaczeń, w czym przypomina na przykład figury Rorschacha ${ }^{16}$.

Soczewkę semantyczną odróżnia od innych postaci, symboli, atrybutów itp. to, że stanowi motyw bardzo szeroko rozpowszechniony w najróżniejszych kontekstach kulturowych i historycznych. Bez względu na kontekst

${ }^{16}$ Por. E. Aphek, Y. Tobin, The Semiotics of Fortune-telling, s. 19-22. 
przedstawienia soczewek semantycznych łączy je uderzające podobieństwo z racji wzorowania ich ikonografii na obserwowalnych uniwersalnych fenomenach (na przykład anatomicznych, jak w przypadku szkieletu ludzkiego). Jednocześnie, pomimo formalnych podobieństw w zakresie sposobu ich przedstawiania, przypisywane im znaczenia w określonych kontekstach pozostają bardzo zróżnicowane, a często nawet skrajnie sprzeczne.

Soczewka semantyczna posiada zatem pewien twardy rdzeń - względnie uniwersalną formę oraz niezwykle elastyczną otoczkę - bardzo zróżnicowaną treść, całkowicie zależną od danego kontekstu. Owo paradoksalne połączenie uniwersalności z partykularyzmem, silnego przyciągania powszechnej uwagi i zarazem generowania skrajnie zróżnicowanych skojarzeń i interpretacji sprawiają, że soczewki semantyczne bardzo łatwo wpasowują się zarówno w kolektywne systemy wierzeń, jak i bardzo indywidualne wizje świata ${ }^{17}$.

Soczewki semantyczne stanowią doskonałe narzędzia do tworzenia pomostów pomiędzy najróżniejszymi systemami znaczeń i kodów estetycznych. z racji swojej formalnej uniwersalności i treściowej różnorodności często służą jako wspólne mianowniki w procesach synkretyzacji na wszelkich pozio$\operatorname{mach}^{18}$.

Obok czaszki, czy generalnie ludzkiego szkieletu, niezwykle wyrazistymi przykładami soczewek semantycznych są wszelakie symbole seksualne. Znaczenie symboliczne przypisywane czynnościom i narządom płciowym w odmiennych kontekstach kulturowych i historycznych są skrajnie różne, choć ikonografia siłą rzeczy często pozostaje zbliżona. Rozważmy choćby zewnętrzne narządy płciowe żeńskie (pudendum).

Na niektórych starych irlandzkich kościołach do dziś można zobaczyć słynne Sheelagh na gig. Są to kamienne płaskorzeźby przedstawiające kobiety, zwykle staruszki eksponujące swoje ogromne, groteskowe pudendum. $\mathrm{w}$ tym konkretnym przypadku odnoszą się one symbolicznie do celtyckiej tradycji, w której władzę królewską przypieczętowywał związek króla z boginią terytorialną ${ }^{19}$. Bogini, chcąc poddać próbie kandydata na króla, odwie-

${ }^{17}$ Por. koncepcja „otwartości” u U. Eco. Soczewka semantyczna dzieli pewne cechy z "dziełem otwartym” (takie jak otwartość i wieloznaczność) opisane przez U. Eco w jego analizie estetyki współczesnej poetyki. Zob. U. Eco, Dzieło otwarte.

${ }^{18}$ Por. koncepcja semiosfery J. Łotmana. Soczewka semantyczna może pełnić funkcję jednego z filtrów niezbędnych w procesie semiozy zachodzących na obrzeżach semiosfery. Zob. Y. Lotman, La semiosfera.

${ }^{19}$ Sama nazwa Irlandia w myśl legend ma wywodzić się od terytorialnej bogini imieniem Ériu. 
dzała go w postaci starej wiedźmy. Jeśli udało jej się go uwieść, zamieniała się w piękną młodą kobietę, a król przechodził próbę i zyskiwał jej błogosławieństwo ${ }^{20}$.

Dla kontrastu dla rdzennych mieszkańców Nowej Gwinei kobiece narządy płciowe i ich wydzieliny obłożone są licznymi tabu, pozostając obiektem najwyższego obrzydzenia i strachu, związanego z przypisywanym im złowrogim, zakaźnym właściwościom ${ }^{21}$.

Z kolei w hinduskiej tradycji śaktycznej i śakta-tantrycznej joni jest symbolem najwyższej zasady kosmicznej: Bogini (Dewi), zwanej Mocą (Śakti). Joni oznacza w języku sanskryckim między innymi „łono, srom, waginę, źródło, początek, gniazdo, dom”. Etymologicznie, podobnie jak słowo joga, wywodzi się od rdzenia * $y u$ oznaczającego „łączyć, jednoczyć” i oznacza „to co łączy”. Wraz z fallicznym symbolem lingą joni symbolizuje dwie kosmiczne zasady: czynną (reprezentowaną przez boginię Śakti ${ }^{22}$ ) i bierną (reprezentowaną przez boga Śiwę). Joni i linga obrazują odwieczny proces kosmicznej kreacji poprzez rozszczepienie świadomości absolutu i cykliczny powrót do źródłowego niezróżnicowania poprzez zjednoczenie przeciwieństw. w geografii mitycznej joni symbolizuje najświętsze miejsce śaktów, w którym znajduje się główna świątyni Bogini. w tradycji kaulów - jednej z sekt tantrycznych wydzieliny pochwowe kojarzone były symbolicznie z wiedzą i poznaniem. Aby uzyskać wtajemniczenie i stać się członkiem klanu adept musiał rytualnie napić się wydzielin pochwowych jednej z członkiń sekty ${ }^{23}$.

Innym przykładem soczewki semantycznej może być fenomen bliźniąt. Nawet żyjącemu w całkowicie „odczarowanym” świecie współczesnemu członkowi post-industrialnego społeczeństwa rzadko zdarza się przejść obok bliźniąt zupełnie obojętnie. Nic dziwnego, że w różnorodnych kontekstach historycznych i kulturowych bliźniętom przypisuje się szczególne właściwości i często odgrywają istotne role w mitach. w obu Amerykach mitycznym bliźniętom bardzo często przypada rola bohaterów kulturowych. Jednak nawet na tym obszarze istnieją znaczące różnice $\mathrm{w}$ sposobie przedstawiania i postrzegania tego fenomenu. w wielu rdzennych amerykańskich mitach, takich jak choćby opowieść z Popol Vuh bliźniacy stanowią doskonale zgra-

${ }^{20}$ M. R. Dexter, s. Goode, The Sheela na gigs, Sexuality and the Goddess in Ancient Ireland, s. 50-75.

${ }^{21}$ Zob. D. Gilmore, Mizoginia, czyli męska choroba, s. 33-56.

${ }^{22}$ Zob. P. G. Michalik, Trucizna i remedium. Paradoksalność mocy w metafizyce śiwaizmu kaszmirskiego, s. 37-58.

${ }^{23}$ Zob. D. G. White, Kiss of the Yoginï? "Tantric Sex" in its South Asian Context. 
ną parę poszukiwaczy przygód, podobnie jak greccy Dioskurowie czy indyjscy Aświnowie. Jednak w innych narracjach (jak choćby w słynnym micie kosmogonicznym Irokezów) jeden z nich jest dobry, a drugi na wskroś zły i sprowadza na świat wszystkie nieszczęścia. Narodziny bliźniąt nie wszędzie uznaje się za „podwójne błogosławieństwo”. Choć w niektórych regionach Afryki i obu Ameryk bliźniętom przypisywano dobroczynne moce, w innych posiadanie bliźniąt kojarzono z nieszczęściem i jedno z nich zwyczajowo zabijano $^{24}$.

Przyciąganie uwagi, szczególnie wyróżnianie się, niemożliwość przejścia obojętnie obok danego fenomenu, wydają się generalnie leżeć u podstaw rdzennych amerykańskich koncepcji „niezwykłości” kojarzonej z sacrum, wyrażanej poprzez takie określenia, jak wakan, orenda i manitou ${ }^{25}$. w kontekście myśli chrześcijańskiej zjawiska wywołujące powszechne poruszenie bywają kojarzone z tym, co święte, nadnaturalne, cudowne lub przeciwnie: tym, co wynaturzone, diabelskie i nieczyste ${ }^{26}$.

Soczewki semantyczne, jako uderzające i łatwo rozpoznawalne zjawiska stymulujące tworzenie linków pomiędzy różnorodnymi systemami znaczeń, zyskują szczególną wagę w erze informacji. Lawina obrazów i koncepcji zalewająca zewsząd współczesnego człowieka stwarza desperacką potrzebę ustanawiania punków skupienia - jednostek znaczących umożliwiających dokonywanie połączeń. Takie punkty odniesienia umożliwiają kanalizowanie chaotycznego przepływu zróżnicowanych informacji. Pozwalają na porządkowanie owych informacji, wtłaczanie ich w ustaloną, ale zarazem wysoce receptywną formę. Ułatwiają orientację w bezładnej plątaninie systemów znaczeń. Łatwo przyjmują rolę dominant semantycznych ${ }^{27}$, kluczy organizujących poszczególne wizje świata.

W przypadku Santa Muerte już na płaszczyźnie wizualnej widać wyraźnie sposób działania soczewki semantycznej, której twardy rdzeń stanowi w tym przypadku przedstawienie ikonograficzne odwołujące się do ludzkiego szkieletu. Szkieletowata postać, czaszka zamiast twarzy, tworzą wspólne, wizualne ogniwo umożliwiające niektórym wyznawcom kojarzenie Świętej

${ }^{24}$ L. S. Milner, Hardness of Heart / Hardenss of Life. The Stain of Human Infanticide, s. 461-465.

${ }^{25}$ Odpowiednio u Siuksów, Irokezów i Algonkinów. Zob. P. G. Michalik, Wiedźmy, święte i boginie. Postać kobiety $w$ wierzeniach Indian z gór Zongolica $w$ Meksyku, s. 18.

${ }^{26}$ Por. koncepcja „kozła ofiarnego” u Girarda, w szczególności szeroko rozpowszechnionej skłonności do wyznaczania ofiary prześladowań na podstawie jej znaków szczególnych; cech, które sprawiały, że wyróżniała się spośród reszty społeczeństwa. Zob. R. Girard, Kozioł ofiarny.

${ }^{27}$ Zob. B. Uspieński, Historia i semiotyka, s. 36-37. 
Śmierci z Mictlantecuhtlim lub Mictlantecíhuatl - azteckimi bóstwami Krainy Zmarłych. Jedną z konsekwencji takich skojarzeń jest nurt neopogański rozwijający się prężnie w ostatnich latach wśród wyznawców Santa Muerte. Inni łączą z kolei Świętą z Oyá - jedną z orishas (postaci mitycznych) wywodzących się z afrokubańskiej santerii. Bardzo charakterystycznym symbolem Oyá jest ludzka czaszka. Hurtowemu importowi do ikonografii Świętej Śmierci estetyki Heavy Metal-Fantasy, kojarzonej wtórnie z popularną ezoteryką, również w ogromnej mierze sprzyja wspólny element: przedstawienie ludzkich szczątek, najczęściej w postaci czaszki lub szkieletu.

Wydaje się zatem, że ów charakter soczewki semantycznej można uznać za jeden z bardzo istotnych czynników kryjących się za nadzwyczajną i wciąż rosnącą popularnością Santa Muerte.

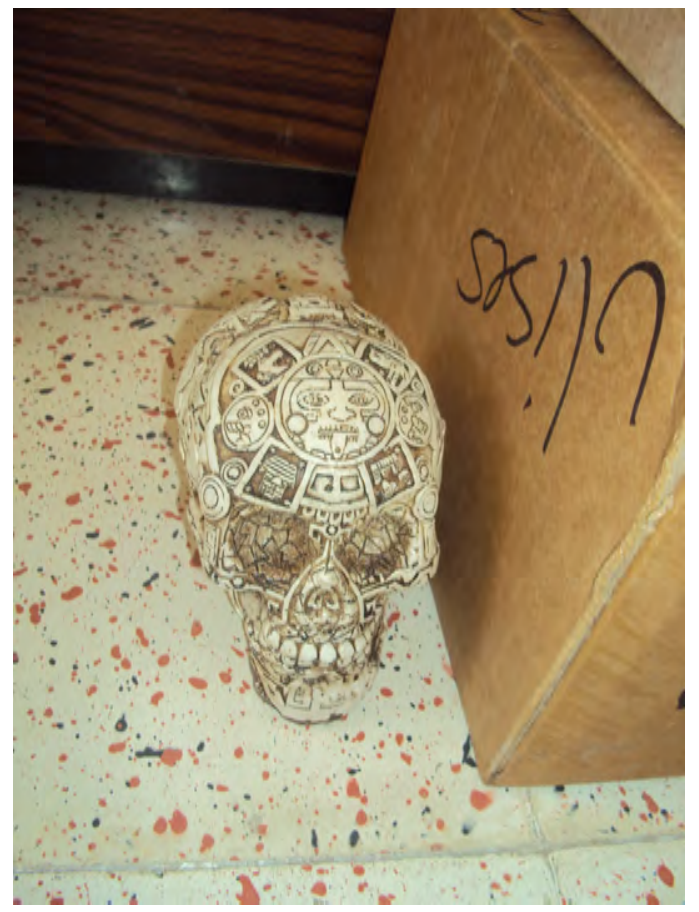

Fot. 10: Czaszka ozdobiona motywami azteckimi zainspirowanymi Piedra del Sol, związana z neopogańskim nurtem w obrębie kultu Świętej Śmierci, sklep ezoteryczny Kriska, Mérida, Jukatan, Meksyk. 


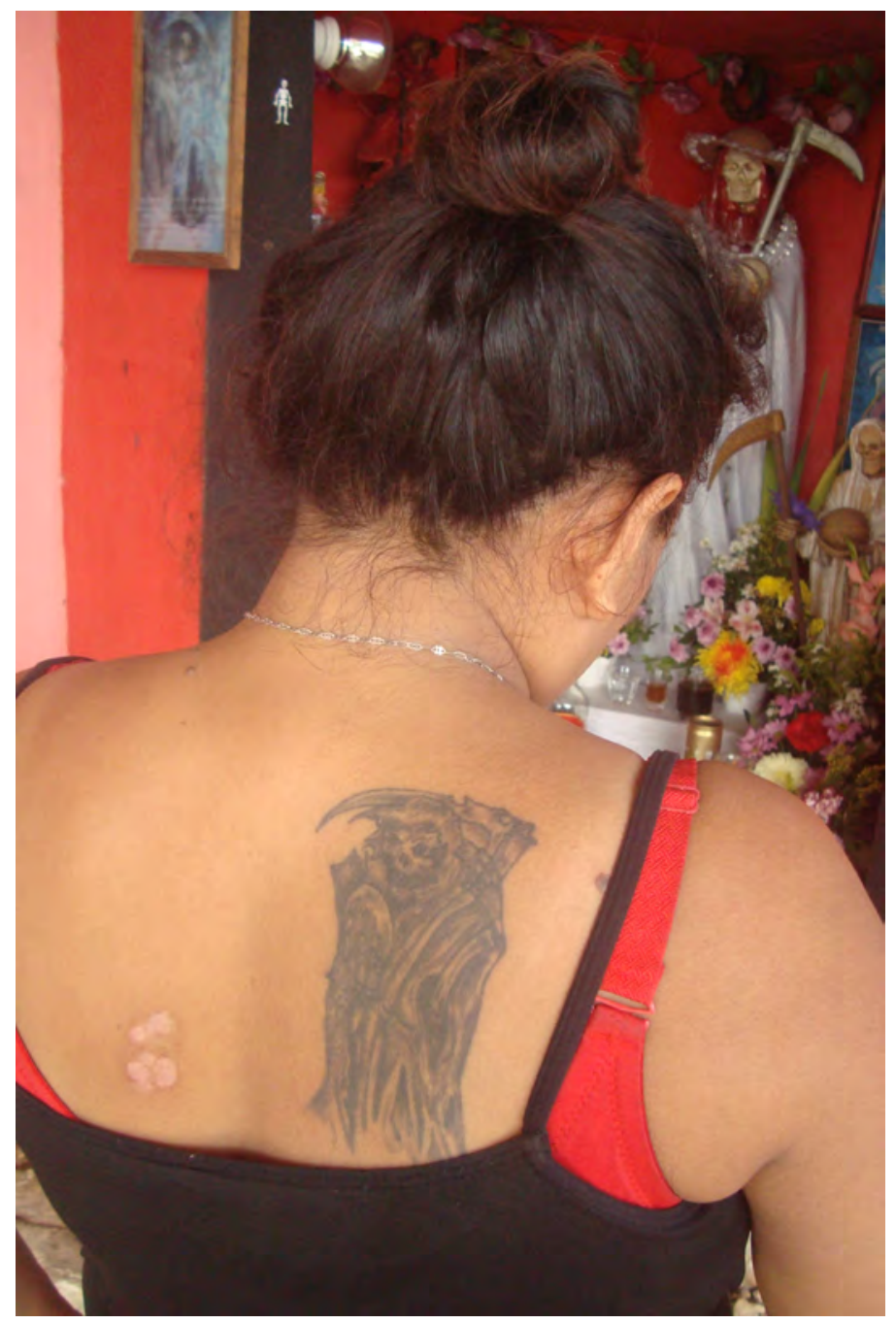

Fot. 11: Tatuaż przedstawiający Świętą Śmierć zdobiący plecy doñi Teresy, właścicielki jednej z kapliczek w Mérida, Jukatan, Meksyk. 


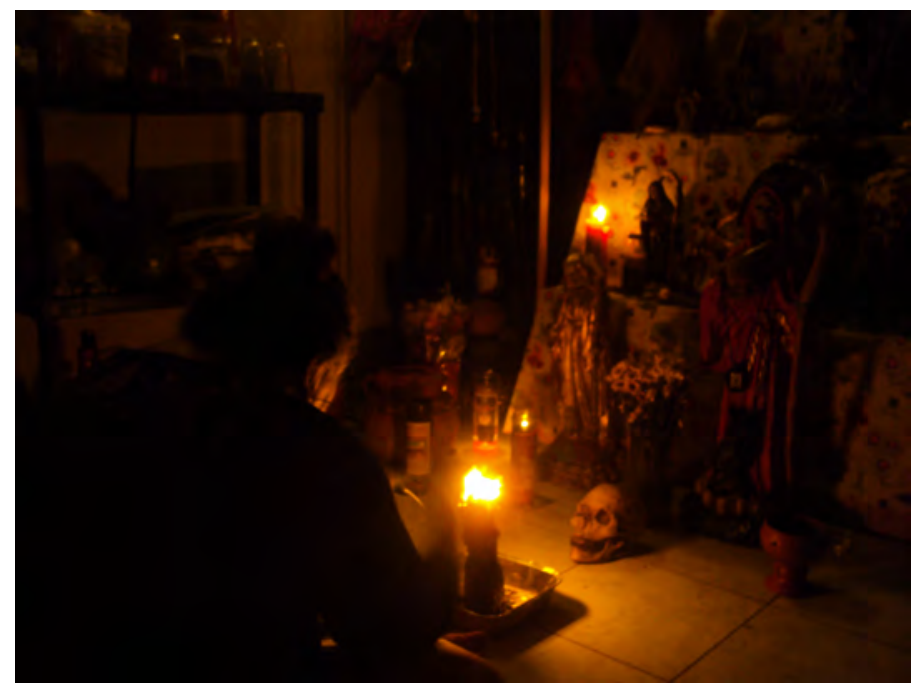

Fot. 12: Doña Martha rzuca uroki przed swoim domowym ołtarzem Świętej Śmierci, Mérida, Jukatan, Meksyk.

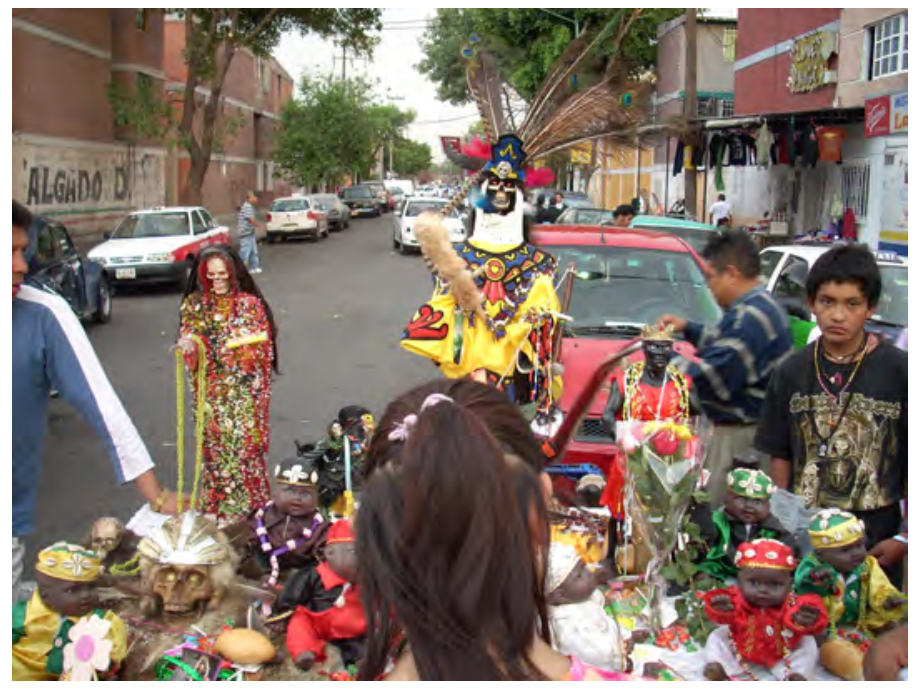

Fot. 13: Przenośny ołtarz Świętej Śmierci łączący elementy neopogańskie (figura w centrum w przebraniu tancerza conchero) i kubańskiej santerii (lalkifigurki reprezentujące orishas), podczas modlitwy różańcowej skierowanej do Santa Muerte, kapliczka Świętej Śmierci doñi Enriquety, Mexico City. 


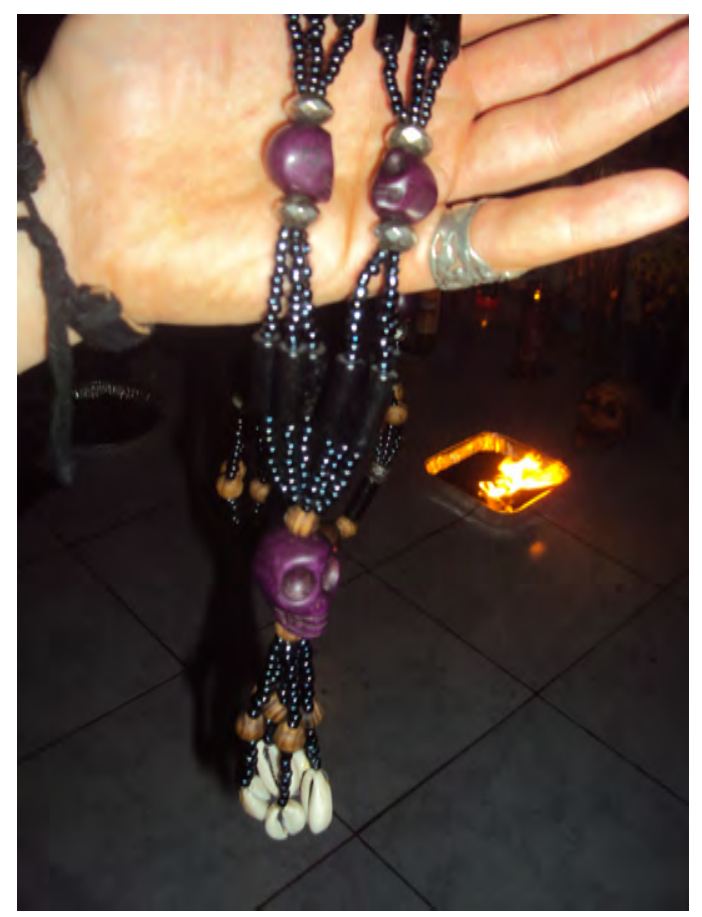

Fot. 14: Różaniec Świętej Śmierci zainspirowany naszyjnikami z koralików (elekes) charakterystycznymi dla orisha Oyá z kubańskiej santerii.

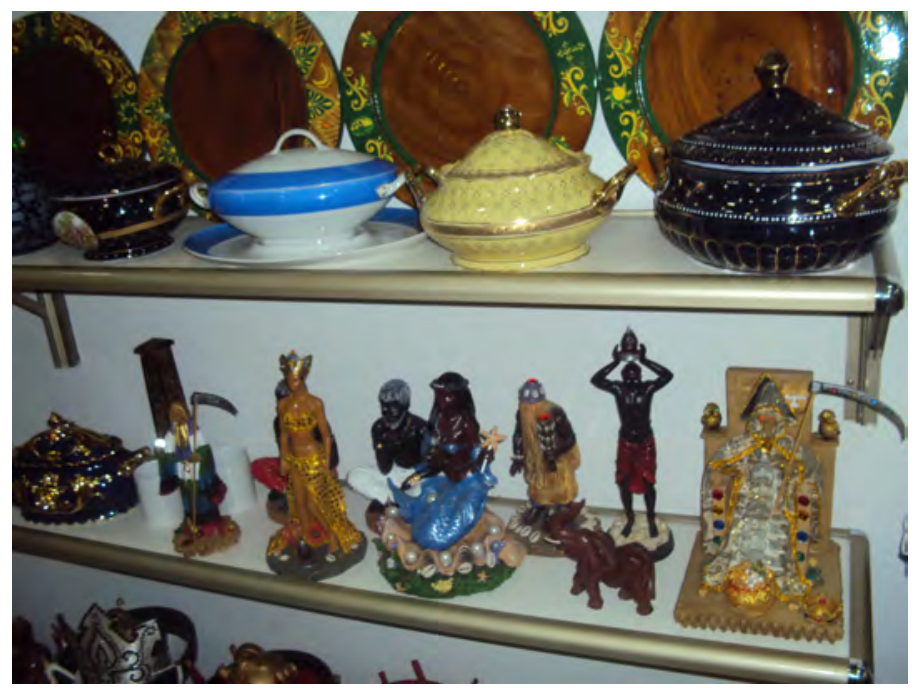

Fot. 15: Figurki Świętej Śmierci znajdujące się obok figurek orishas, sklep ezoteryczny w Hawanie, Kuba. 


\section{Bibliography}

1. Adeath C., Kristensen R., La Muerte de tu lado, Mantarraya Ediciones, México D.F. 2007.

2. Aguirre Beltrán G., Medicina y magia. El proceso de aculturación en la estructura colonial, INI, México 1980.

3. Aldred L., Plastic Shamans and Astroturf Sundances. New Age Commercialization and Native American Spirituality, „The American Indian Quarterly" 24 (3/2000), s. 329-352.

4. Арнек E., Toвin Y., The Semiotics of Fortune-telling, John Benjamins Publishing, Amsterdam 1990.

5. Chesnut A. R., Devoted to Death. Santa Muerte, the Skeleton Saint, Oxford University Press, Oxford - New York 2012.

6. Dexter M. R., Goode S., The Sheela na gigs, Sexuality and the Goddess in Ancient Ireland, „Irish Journal of Feminist Studies” 4 (2/2002), s. $50-75$.

7. Eco U., Dzieto otwarte, W.A.B., Warszawa 2008.

8. Eco U., Nieobecna struktura, KR, Warszawa 2003.

9. Flores Martos J. A., La Santísima Muerte en Veracruz, México: vidas descarnadas y prácticas encarnadas, [w:]: Etnografías de la muerte y las culturas en América Latina, J. A. Flores Martos, L. Abad Gonzáles (red.), Ediciones de la Universidad de Castilla-La Mancha, La Mancha 2007, s. $273-304$.

10. Girard R., Koziot ofiarny, Wydawnictwo Łódzkie, Łódź 1991.

11. Gilmore D. D., Mizoginia, czyli męska choroba, Wydawnictwo Literackie, Kraków 2003.

12. HanegraAff W. J., New Age Religion and Western Culture. Esotericism in the Mirror of Secular Thought, E. J. Brill, Leiden 1996.

13. JuÁrez Huet N.B., Un pedacito de dios en casa. Circulación transnacional, relocalización y praxis de la santería en la Ciudad de México, Publicaciones de la Casa Chata, México 2014.

14. Lagarriga Attias I., Espiritualismo trinitario mariano. Nuevas perspectivas

15. de analisis, Universidad Veracruzana, Xalapa 1975.

16. Lamas M., By Night a Street Rite. 'Public' Women of the Night on the Streets of Mexico City [w:] Gender's Place. Feminist Anthropologies of Latin America, R. Montoya, L. J. Frazier, J. Hurtig, (red.), Palgrave MacMillan, New York 2002, s. 238-253. 
17. Lewis O., Los hijos de Sanchez, Fondo de Cultura Economica, México D.F. 1964.

18. Lomnitz C., Idea de la muerte en Mexico, Fondo de Cultura Economica, México D.F. 2006.

19. Lotman Y., La semiosfera, Catedra, Madrid 1996.

20. Malvido E., Crónicas de la Buena Muerte a la Santa Muerte en México, „Arqueología Mexicana” 76 (13/2005), s.20-27.

21. Michalik P. G., Death with a Bonus Pack: New Age Spirituality, Folk Catholicism and the Cult of Santa Muerte, „Archives de sciences sociales des religions" 153 (2011), s. 159-182.

22. Michalik P. G., Trucizna i remedium. Paradoksalność mocy w metafizyce śiwaizmu kaszmirskiego, „Przegląd religioznawczy” 3 (2006), s. $37-58$.

23. Michalık P. G., Wiedźmy, święte i boginie. Postać kobiety w wierzeniach Indian z gór Zongolica $w$ Meksyku, Nomos, Kraków 2013.

24. Milner L. S., Hardness of Heart / Hardenss of Life. The Stain of Human Infanticide, University Press of America, Lanham/New York/Oxford 2000.

25. Navarrette C., San Pascualito Rey y el culto a la muerte en Chiapas, UNAM, México D.F. 1982.

26. Ortiz Echanizn S., Una religiosidad popular: el espiritualismo trinitario mariano, INAH, México D.F. 1990.

27. Perdigón Castañeda K., La Santa Muerte. Protectora de los hombres, INAH, México D.F. 2008.

28. UspieŃski B., Kult Świętego Mikołaja na Rusi, KUL, Lublin 1985.

29. Uspieński B., Historia i semiotyka, Słowo/obraz Terytoria, Gdańsk 1998.

30. White D. G., Kiss of the Yoginï? "Tantric Sex" in its South Asian Context, University of Chicago Press, Chicago 2003. 


\title{
Abstract, keywords, about the author
}

\begin{abstract}
The article provides an overview of chosen aspects of the cult of Santa Muerte („Saint Death”) in Mexico from a semiotic perspective. What distinguishes Santa Muerte from other Mexican folk Saints is her astonishing, constantly growing popularity in recent decades, as well as her exceptional receptiveness to elements originating from diverse currents of popular religiosity, including commercial esoterics, neopagan practices, and Cuban Santeria. These differentials can be explained by indicating a set of particular features that enable to qualify Saint Death as a „semantic lens”.
\end{abstract}

Keywords: Santa Muerte, Mexico, folk Saints, semiotics

Piotr Grzegorz Michalik PhD assistant professor at the Centre for Comparative Studies of Civilisations of Jagiellonian University. Since 2007 regulary conducts fieldwork in Mexico. Additionally carried out several research expeditions to Guatemala and Cuba. Author of distinguished publications on Mexican folk Saints and Mesoamerican indigenous beliefs.

E-MAIL: piotr.michalik@uj.edu.pl 